\title{
SOIL PROPERTIES IN SCOTS PINE (PINUS SYLVESTRIS L.) STANDS IN TERVETE NATURE PARK IN LATVIA
}

Inga STRAUPE, Department of Silviculture, Forest Faculty, Latvia University of Life Sciences and Technologies, Akademijas iela 11, Jelgava, LV-3001, Latvia, inga.straupe@1lu.lv (corresponding author)

Aigars INDRIKSONS, Department of Silviculture, Forest Faculty, Latvia University of Life Sciences and Technologies, Akademijas iela 11, Jelgava, LV-3001, Latvia, aigars.indriksons@1lu.lv

Ieva ERDBERGA, Institute of Soil and Plant sciences, Faculty of Agriculture, Latvia University of Life Sciences and Technologies, Akademijas iela 11, Jelgava, LV-3001, Latvia, ieva.erdberga@1lu.lv

Anna DUVINA, Department of Silviculture, Forest Faculty, Latvia University of Life Sciences and Technologies, Akademijas iela 11, Jelgava, LV-3001, Latvia, annjuks2@inbox.lv

A research of soil properties was carried out in 2020 in the area of unique old Scots pine (Pinus sylvestris L.) stands in Tervete Nature Park in Latvia. The oldest tree stands reaches age of 180 till 260 years. These are the oldest pine stands in Latvia and in Baltic countries still growing in nowadays. As in the vicinity of Tervete there is a pronounced moraine undulating relief, and the sediments are formed by moraine loam of various thicknesses, then part of the pleasant conditions for pine is already provided in the soil. But still the soils in pine stands of Tervete are poorly studied.

In July of 2020 there were soil description in 8 pine stands provided to get the information of most important soil parametres: genetic horizons, texture, percentage of clay content, soil structure, colour, $\mathrm{pH}$, carbonates, percentage of organic matter, sum of adsorbed bases, content of $\mathrm{P}_{2} \mathrm{O}_{5} \mathrm{mg} \mathrm{kg}^{-1}$ of soil. The results of soil analyses were compared to tree stand characteristics. The soil types Cambisol and Arenosol were represented in researched stands. Although the content of calcium carbonates has been considered as an prerequisite of soil fertility, only the part of stands had the carbonates abundant in the soil horizons up to $80 \mathrm{~cm}$. The development of Scots pine stands was found to be equal both in sites with the sand and clay content dominating in the soil.

Keywords: soil properties, Scots pine, calcium carbonates, Tervete Nature Park.

\section{INTRODUCTION}

Tervete Nature Park is a nature park located in the territory of Tervete (1148 ha or 84\%) and Jelgava (218 ha or 16\%) Municipalities in Zemgale Plain in Latvia. It covers an area of 1366 ha and belongs to the Zemgale geobotanical district. In the territory of the nature park there is an ancient valley of the Tervete River with a scenically unique pine forest tract.

The 1999 Regulations of the Cabinet of Ministers of Latvia "On Nature Parks" approved the Tervete Nature Park as a protected territory. Since 2000 the park is managed by the Joint Stock Company "Latvian State Forests". In 2005, nature park was included in the European network of specially protected nature territories Natura 2000 (Straupe, 2009).

Especially valuable part of the nature park is the area of old Scots pine (Pinus sylvestris L.) stands, which are characterized by the structure of natural forests. The age of oldest stands reaches of 260 years whose area takes about 30 hectares. The average age of pines in the nature park reaches 104 years. Such stands are considered to be biologically old pine stands that need to be preserved for the future development of biodiversity.

An unresolved issue is the origin of these pine stands, as the local conditions are not typical of its growth. The potentially rich, carbonate saturated sediments of moraine would be more favorable for establishment of stands of nutrient more demanding species, e.g., Norway spruce (Picea abies (L.) H.Karst.) or broadleaves. In generally, Scots pine has a wide ecological range; it grows in both poor sandy soils and wet peat soils. In fertile soils, pine grows branched, with wide annual rings and is therefore of low value. Pine grows best in lightly clayey sandy soil, where it can reach a height of up to 40 meters. Historically, the highest pines in Latvia have been found in Tervete forest $(47.2 \mathrm{~m}$ with a diameter 70 $\mathrm{cm}$ ). The rich understorey of common hazel (Corylus avellana L.), rowan (Sorbus aucuparia L.) and other shrub species provides the necessary nutrients to the soil. Pines grow in both pure and mixed forests together with Norway spruce, birch (Betula sp.), less often with common oak (Quercus robur L.), common aspen (Populus tremula L.) and other deciduous tree species. Pure stands are usually formed in poor sandy soils and wet peat soils (LVM dabas..., 2020).

Copyright () 2021 The Authors. Published by Vytautas Magnus University. This is an open-access article distributed under the terms of the Creative Commons Attribution License (CC BY 4.0), which permits unrestricted use, distribution, and reproduction in any medium, provided the original author and source are credited. 
The pine growing on fertile soils as a special case in Latvian forest typology is described by K. Buss (1981) - the establisher of modern national forest typology in Latvia. For the forest site type Hylocomiosa distinguishes a separate variant with the Latvian name - dizsils (translated to English - "great forest"). As such sites are rare, they are not singled out as separate forest site type in modern forest typology. Pine forests on fertile soils are found in the Zemgale Plain on flat or slightly undulating terrain. It is characterized by high-yielding I and Ia site index classes pine stands, where there is also a small admixture of deciduous trees - common oak, birch species etc. The second floor of the stand consists of common oak, small-leaved linden (Tilia cordata Mill.), Norway maple (Acer platanoides L.) and common ash (Fraxinus excelsior L.). The most characteristic species of understorey are the alder buckthorn (Frangula alnus Mill.), rowan and the guelder-rose (Viburnum opulus L.) (Buss, 1981).

According to the Nature protection plan of Tervete Nature Park (Straupe, 2009), the largest areas in nature park are occupied by boreal forests (naturally old pine forests), which are especially important for the preservation of biodiversity and the characteristic landscape of the nature park. The protected area represents 11 specially protected habitats in Latvia and 9 in Europe: boreal forests - 117.7 ha, mixed broad-leaved forests - 22.0 ha, slope and ravine forests - 3.11 ha, a complex consisting of wet broad-leaved forests and mineral-rich springs and spring mires - 36.3 ha, black alder swamps - 0.3 ha, dry meadows in calcareous soils - 11.6 ha, moderately moist meadows - 11.7 ha and plain to mountain level watercourses with Ranunculion fluitantis and Callitricho-Batrachion vegetation - 3.5 ha (Straupe, 2009).

As the vegetation is one of the most important sites forming factors, it has been inventoried several times (1957, 2003; 2013, 2018), to follow its succession (Cekstere, 1957; Straupe and Adamovics, 2003; Namniece, 2005; Danilevica, 2019). The results of these inventories show the gradually decrease in species number in plots inventoried: 195 in 1957 , 121 in 2003, 76 in 2013 and 57 in 2018. The plots show an increase of nemoral species. Ellenberg`s ecological indicators show a decrease in light conditions, but the amount of nitrogen in the soil is increasing significantly (Danilevica, 2019). In generally, these results correspond to the natural processes in a forest ecosystem.

Since the second half of last century, a special interest of forest managers and scientists concerns to further development of Scots pine stands in Tervete Nature Park (Avotins, 1967; Gedrovica, 1968; Namniece, 2005; Straupe, 2009). Will the Scots pine regenerate successfully in sites of old stands? Will this process proceed naturally or some human's intervention is needed? In generally, the regeneration of Scots pine is difficult in sites rich of nutrients because of competition by herbaceous vegetation and fast-growing deciduous trees. Additionally, as a result of the eutrophication process, favorable environmental conditions are ensured for the spread of non-characteristic herbaceous plant and shrub species, which inhibit the natural regeneration of Scots pine seedlings.

Soil is probably one of the key elements in resolving these issues. The research of soil properties in Scots pine stands in Tervete could give an answer: why pine growth is here so favorable? Which soil properties are predicting the best growth of pine? There are only few evidences of land use history in these sites. As a lot of meadow plant species were found by first inventory, a hypothesis that Tervete pine stands were established in sites of overgrown pastures (Cekstere, 1957). Also, the forest scientists A. Zviedris and J. Matuzanis (1960) suggest that, analyzing the soil profiles, a part of stands of Hylocomiosa forest site type in Zemgale Plain, with Scots pine as dominant species, were established by sowing pine on former arable land. However, there is not direct reference to pine stands in Tervete.

\section{METHODS}

Soil data were collected in eight permanent sample plots in forests in the territory of the Tervete Nature Park in seven forest quarters: 192, 195, 211, 210, 216, 217 and 218 (Table 1). The size of each plot is $400 \mathrm{~m}^{2}$ or $20 \mathrm{~m} \times 20 \mathrm{~m}$. These plots before were used also for vegetation survey and for tree stand parameters estimation. The initial aim of forest quarters selection, made by plot's establishers in 50-ties of last century, most likely was to characterize the pine stands in different location in Tervete. All quarters where the plots are established are located in the area of nature reserve, except of quarter 211. It means that in majority of researched stands the forest management activities are limited.

The soils were characterized by using the probing method. A one-meter-long metallic probe was used to obtain the depth and sequence of soil genetic horizons. The soil probe was taken in one characteristic (of average conditions) point per each sample plot. The horizon's description, photography and the field estimation of carbonates with 10 percent hydrochloric acid $(\mathrm{HCl})$ was made on site. The soil samples from the probe were taken for each horizon and placed in the plastic bags for transport to the laboratory.

The analyzes of the soil physical and chemical parameters were made in the Laboratory of Soil and Agrochemistry of Latvia University of Life Sciences and Technologies located in the city of Jelgava.

Soil type, including all necessary characteristics, was determined using the national and the World Reference Base (WRB) systems (Augsnes diagnostika..., 2008; Food and Agriculture Organization..., 2015).

Dertermination of soil $\mathrm{pH}: 10 \mathrm{~g}$ of air-dry soil ( $2 \mathrm{~mm}$ sieve) is covered with $25 \mathrm{~mL}$ of deionized water or $1 \mathrm{M} \mathrm{KCl}$ . The suspension is shaken for 1.5 hours in a rotating motion. The $\mathrm{pH}$ is determined potentiometrically.

The amount of organic matter $(\%)$ in mineral soil samples was determined using the Walkley-Black method, in soil samples of organic origin (surface horizons) it was determined by ashing method at $500^{\circ} \mathrm{C}$ (Matus et al., 2009). 
Table 1. Tree stand characteristics in sample plots

\begin{tabular}{|c|c|c|c|c|c|c|c|}
\hline No. & $\begin{array}{l}\text { Quar- } \\
\text { ter }\end{array}$ & $\begin{array}{l}\text { Sub- } \\
\text { quarter }\end{array}$ & $\begin{array}{c}\text { Stand } \\
\text { composition } \\
\text { formula }\end{array}$ & $\begin{array}{l}\text { II-nd floor } \\
\text { of tree } \\
\text { stand }\end{array}$ & $\begin{array}{l}\mathrm{H}, \\
\mathrm{m}\end{array}$ & $\begin{array}{l}\mathrm{D}, \\
\mathrm{cm}\end{array}$ & Undergrowth, understorey \\
\hline 1. & 192. & 1. & 10Pine $_{170}$ & - & 31 & 54 & $\begin{array}{l}\text { Medium dense - Corylus avellana L., Acer platanoides } \\
\text { L., Frangula alnus Mill., Padus avium (L.), Lonicera } \\
\text { xylosteum L., Sorbus aucuparia L. }\end{array}$ \\
\hline 2. & 195. & 9. & 10Pine 180 & $\begin{array}{l}\text { +Linden, } \\
\text { Oak66 }\end{array}$ & 33 & 56 & $\begin{array}{l}\text { Medium dense - Corylus avellana L., Lonicera } \\
\text { xylosteum L., Rhamnus cathartica L., Ribes rubrum L. }\end{array}$ \\
\hline 3. & 195. & 8. & 8Pine $_{70}$ 2Pine $_{100}$ & - & 28 & 31 & $\begin{array}{l}\text { Medium dense - Corylus avellana L., Lonicera } \\
\text { xylosteum L., Tilia cordata Mill. }\end{array}$ \\
\hline 4. & 211. & 2. & 9Pine1Spruce 135 & 1Spruce76 & 35 & 45 & $\begin{array}{l}\text { Medium dense - Corylus avellana L., Picea abies (L.) } \\
\text { H.Karst., Lonicera xylosteum L., Tilia cordata Mill. }\end{array}$ \\
\hline 5. & 210. & 2. & 10Pine $_{105}$ & + Spruce $_{66}$ & 33 & 35 & $\begin{array}{l}\text { Medium dense - Corylus avellana L., Lonicera } \\
\text { xylosteum L., Padus avium (L.), Picea abies (L.) } \\
\text { H.Karst., Ribes rubrum L., Tilia cordata Mill., Ulmus } \\
\text { glabra Huds. }\end{array}$ \\
\hline 6. & 216. & 5. & 10Pine 161 & $\begin{array}{l}+ \text { Oak, } \\
\text { Maple } 37\end{array}$ & 36 & 48 & $\begin{array}{l}\text { Dense - Corylus avellana L., Padus avium (L.), Lonicera } \\
\text { xylosteum L., Tilia cordata Mill., Sorbus aucuparia L, } \\
\text { Acer platanoides L. }\end{array}$ \\
\hline 7. & 217. & 1. & 10Pine 161 & $\begin{array}{l}\text { +Oak, } \\
\text { Salix } \\
\text { caprea L.37 }\end{array}$ & 35 & 47 & $\begin{array}{l}\text { Dense - Corylus avellana L., Picea abies (L.) H.Karst., } \\
\text { Populus tremula L. }\end{array}$ \\
\hline 8. & 218. & 1. & 10Pine 161 & $\begin{array}{l}\text { +Oak, } \\
\text { Maple }_{37}\end{array}$ & 35 & 43 & Dense - Corylus avellana L., Picea abies (L.) H.Karst. \\
\hline
\end{tabular}

Small numbers (in subscript) - the age of tree stand.

The sum of the adsorbed bases was determined with $0.1 \mathrm{M} \mathrm{HCl}$ using $0.1 \mathrm{M} \mathrm{NaOH}$ as the titration solution (Hissink, 1923). Phosphorus in mineral soil samples was determined using the Egner-Rhyming method (Augsnes kvalitate..., 1997).

\section{RESULTS}

The all-researched stands can be considered as pure Scots pine stands with some admixture of other species. The only stand where Norway spruce takes about $10 \%$ of the stands volume is in quarter 211 (the only stand in research, located outside of nature reserve area of nature park). The age of dominant stand varies between 70 and 180 years, so, representing the soils with long-time pine stands growing. As the initial hypothesis suggested the pine stands growth possibly being forced by calcium carbonates richness in parent material of soil (up to 20-30\%) which promotes the formation of sod-calcareous soils, the testing of carbonates content was made for each horizon of each soil profile (probe). The results given in Table 2, show that in five of researched stands, there are no carbonates in upper $80 \mathrm{~cm}$ of the soil.

Table 2. The most important results of analyzes of the soil physical and chemical parameters

\begin{tabular}{|c|c|c|c|c|c|c|c|c|c|}
\hline \multirow{2}{*}{$\begin{array}{l}\text { Quarter, } \\
\text { sub- } \\
\text { quarter }\end{array}$} & \multirow[b]{2}{*}{$\begin{array}{c}\text { Hori- } \\
\text { zon }\end{array}$} & \multirow[b]{2}{*}{ Depth, cm } & \multicolumn{2}{|c|}{ Soil type } & \multirow[b]{2}{*}{$\begin{array}{c}\mathrm{pH} \\
\mathrm{H}_{2} \mathrm{O}\end{array}$} & \multirow{2}{*}{$\begin{array}{l}\text { Organic } \\
\text { sub- } \\
\text { stances, } \\
\%\end{array}$} & \multirow[b]{2}{*}{ Texture } & \multirow{2}{*}{$\begin{array}{c}\text { Clay } \\
\text { content, } \\
\%\end{array}$} & \multirow[b]{2}{*}{ Carbonates } \\
\hline & & & $\begin{array}{l}\text { Latvian } \\
\text { system }\end{array}$ & WRB & & & & & \\
\hline 192. 1. & $\mathrm{O}$ & $0-4$ & \multirow{5}{*}{$\begin{array}{l}\text { Brown soil } \\
\text { with } \\
\text { residual } \\
\text { carbonates }\end{array}$} & \multirow[b]{5}{*}{ Cambisol } & 6.95 & 54.51 & Raw humus & & Non \\
\hline 192. 1. & Ah1 & $4-15$ & & & 7.41 & 6.9 & Silty loam & $10-27$ & Slightly \\
\hline 192. 1. & Ah2 & $15-30$ & & & 6.72 & 9.05 & Silty loam & $10-27$ & Non \\
\hline 192. 1. & Ah3 & $30-42$ & & & 6.1 & 7.64 & Silty loam & $10-27$ & Slightly \\
\hline 192. 1. & $\mathrm{AE}$ & $42-71$ & & & 5.46 & 1.86 & Silty loam & $10-27$ & Non \\
\hline 195. 9. & $\mathrm{O}$ & $0-4$ & \multirow{5}{*}{$\begin{array}{l}\text { Typic sod- } \\
\text { calcareous } \\
\text { soil }\end{array}$} & \multirow[b]{5}{*}{ Cambisol } & 6.97 & 52.37 & Raw humus & & Non \\
\hline 195. 9. & $\mathrm{OH}$ & $4-17.5$ & & & 7.04 & 34.49 & Loam & $8-27$ & Slightly \\
\hline 195. 9. & Ah1 & $17.5-29$ & & & 7.63 & 2.53 & Silty loam & $<10$ & Slightly \\
\hline 195. 9. & Bsg & $29-55$ & & & 8.16 & 0.9 & Sandy loam & $10-25$ & Slightly \\
\hline 195. 9. & $\mathrm{Bkg}$ & $55-80$ & & & 8.32 & 0.58 & Silty loam & $10-27$ & Strongly \\
\hline 195. 8. & $\mathrm{O}$ & $0-4$ & \multirow{4}{*}{$\begin{array}{l}\text { Sod-gleyic } \\
\text { soil }\end{array}$} & \multirow[b]{4}{*}{ Cambisol } & 7.11 & 43.13 & Raw humus & & Non \\
\hline 195. 8. & Ah1 & $4-18$ & & & 7.56 & 9.45 & Loam & $8-27$ & Slightly \\
\hline 195. 8. & Ah2 & $18-40$ & & & 7.67 & 6.76 & Clay loam & $25-40$ & Slightly \\
\hline 195. 8. & Btg & $40-60$ & & & 8.28 & 0.96 & Sandy clay & $35-55$ & Slightly \\
\hline 211. 2. & $\mathrm{O}$ & $0-6$ & \multirow{4}{*}{$\begin{array}{c}\text { Base-- } \\
\text { unsaturated } \\
\text { brown soil }\end{array}$} & \multirow[b]{4}{*}{ Arenosol } & 5.21 & 38.89 & Raw humus & & Non \\
\hline 211. 2. & $\mathrm{AH}$ & $6-12.5$ & & & 5.48 & 10.83 & Medium sand & $<5$ & Non \\
\hline 211. 2. & $\mathrm{Ah}$ & $12.5-47.5$ & & & 5.75 & 4.92 & Medium sand & $<5$ & Non \\
\hline 211. 2. & Bhs & $47.5-80$ & & & 5.75 & 1.35 & Coarse sand & $<5$ & Non \\
\hline 210.2. & $\mathrm{O}$ & $0-4$ & & Arenosol & 5.6 & 38.51 & Raw humus & & Non \\
\hline
\end{tabular}




\begin{tabular}{|c|c|c|c|c|c|c|c|c|c|}
\hline 210. 2. & Ah1 & $4-24.5$ & \multirow{3}{*}{$\begin{array}{c}\text { Base- } \\
\text { unsaturated } \\
\text { brown soil }\end{array}$} & & 5.92 & 5.7 & Medium sand & $<5$ & Non \\
\hline 210. 2. & Ah2 & $24.5-42$ & & & 5.65 & 4.61 & Fine sand & $<5$ & Non \\
\hline 210.2. & Bsg & $42-$ & & & 5.7 & 1.4 & Medium sand & $<5$ & Non \\
\hline 216.5. & $\mathrm{O}$ & $0-2$ & \multirow{4}{*}{\multicolumn{2}{|c|}{$\begin{array}{c}\text { Base- } \\
\text { unsaturated } \\
\text { brown soil }\end{array}$}} & 6.35 & 43.13 & Raw humus & & Non \\
\hline 216. 5. & Ah1 & $2-23$ & & & 6.83 & 6.64 & Loamy sand & $<12$ & Non \\
\hline 216.5. & Ah2 & $23-48$ & & & 6.82 & 4.91 & Loamy sand & $<12$ & Non \\
\hline 216. 5. & Bsg & $48-84$ & & & 6.8 & 0.87 & Medium sand & $<5$ & Non \\
\hline 217.1. & $\mathrm{O}$ & $0-4$ & \multirow{5}{*}{$\begin{array}{c}\text { Base-- } \\
\text { unsaturated } \\
\text { brown soil }\end{array}$} & \multirow[b]{5}{*}{ Arenosol } & 6.6 & 53.7 & Raw humus & & Non \\
\hline 217.1. & $\mathrm{AH}$ & $4-13.5$ & & & 6.68 & 21.87 & Sandy loam & $<10$ & Non \\
\hline 217.1. & Ah1 & $13.5-20$ & & & 6.75 & 5.01 & Medium sand & $<5$ & Non \\
\hline 217. 1. & Ah2 & $20-43$ & & & 6.06 & 2.6 & Medium sand & $<5$ & Non \\
\hline 217.1. & Bs & $43-80$ & & & 6.44 & 0.82 & Fine sand & $<5$ & Non \\
\hline 218. 1. & $\mathrm{O}$ & $0-8$ & \multirow{5}{*}{$\begin{array}{c}\text { Base- } \\
\text { unsaturated } \\
\text { brown soil }\end{array}$} & \multirow[b]{5}{*}{ Arenosol } & 5.18 & 74.13 & Raw humus & & Non \\
\hline 218.1. & $\mathrm{AH}$ & $8-16.5$ & & & 5.72 & 37.9 & Medium sand & $<5$ & Non \\
\hline 218.1. & $\mathrm{Ah}$ & $16.5-45$ & & & 5.66 & 2.45 & Medium sand & $<5$ & Non \\
\hline 218.1. & Bhs1 & $45-65$ & & & 5.88 & 2.25 & Medium sand & $<5$ & Non \\
\hline 218.1. & Bhs2 & $65-85$ & & & 5.75 & 2.27 & Fine sand & $<5$ & Non \\
\hline
\end{tabular}

The typic sod-calcareous soil is found in the oldest (180 years) pine stand with medium dense understorey and 66 years old 2nd floor of the linden and oak. Essential that stand is located on morainic hill in strongly sloping (15\%) position. Another sites containing carbonates was classified as sod-gleyic soil and brown soil with residual carbonates. The sites not having carbonates in the upper profile were classified as base-unsaturated brown soils. The Cambisol and Arenosol were diagnosed as the basic soil types according to WRB 2014 for researched pine stands.

Not only the carbonates but also, clay content, sum of adsorbed bases and other soil properties are indicators of soil fertility. The clay content varies between less than 5\% in Arenosols till 55\% in site with the Cambisol - the profile is showing also some gleyic properties (sod-gleyic soil), The sum of adsorbed bases fluctuates between 0.6 and $26.9 \mathrm{cmol}(+)$ $\mathrm{kg}^{-1}$ in the analyzed soil horizons being higher in Cambisols - profiles with clay accumulation and carbonates abundance. All profiles analyzed have raw humus layer and first mineral soil horizons rich on organic substances (Table 2). The depth of $\mathrm{A}(\mathrm{Ah})$ horizon in all profiles reaches more than $40 \mathrm{~cm}$, indicating to possible land use for agriculture in the past.

\section{CONCLUSIONS}

The soils in researched pine stands corresponds to the Cambisol and Arenosol types, according to WRB 2014. The variability of soil types by national classification is wider, including sod-gleyic soil, typic sod-calcareous soil, base unsaturated brown soil and the brown soil with residual carbonates.

Only three of eight researched pine stands had the carbonates abundant in the soil horizons up to $80 \mathrm{~cm}$.

The admixture of common oak and other broadleaves in stand composition was not dependent of the carbonates content in the upper soil horizons.

The development of Scots pine stands was found to be equal both in sites with the sand and clay content dominating in the soil.

Acknowledgements. The study was supported by the grant of project of Latvia University of Life Sciences and Technologies "Implementation of LLU research programme".

\section{REFERENCES}

1. Augsnes diagnostika un apraksts. 2008. Sast. A. Karklins. Jelgava: LLU. (in Latvian)

2. Augsnes kvalitāte - kustīgā fosfora un kālija noteikšana ar Egnera-Rīma (DL) metodi. Nozares standarti [Soil quality estimation of mobile phosphorus and potassium with Egner-Rhyming (DL) method. Industry standards]. 1997. Grupa C - 09. Kods 00823701. LV ST ZM 82-97. (in Latvian)

3. Avotins A. 1967. Tervetes meza ainavu parks [Forest landscape park Tervete]. Mezsaimnieciba un mezrupnieciba, No. 1, pp. 55. (in Latvian)

4. Buss K. 1981. Meza ekologija un tipologija [Forest ecology and typology]. Riga: izdevnieciba “Zinatne”, pp. 68. (in Latvian)

5. Cekstere R. 1958. Tervetes mezu vegetacija [Vegetation of Tervete forests], Diploma paper, Riga. (in Latvian)

6. Food and Agriculture Organization of the United Nations. 2015. World reference base for soil resources 2014. International soil classification system for naming soils and creating legends for soil maps. World Soil Resources Report 106. Available at http://www.fao.org/3/i3794en/I3794en.pdf (accessed on 10/05/2021)

7. Danilevica K. 2019. Parastas priedes Pinus sylvestris L. mezu vegetacijas attistiba dabas parka „Tervete” [The development of the Scots pine Pinus sylvestris L. forest vegetation in Nature Park Tervete], Bachelor paper, Forest Faculty, Latvia University of Life Sciences and Technologies, Jelgava. (in Latvian)

8. Gedrovica G. 1968. Tervetes parka apsaimniekosana [Management of Tervete Park]. Mezsaimnieciba un mezrupnieciba, No. 3, pp. 52-54. (in Latvian) 
9. Hissink D. J. 1923. Method for estimating adsorbed bases in soils and the importance of these bases in soil economy. Agricultural Experiment Station, Groningen, Holland. Translated and summarized by F.H. Smith, Georgia Experiment Station. Reprinted from Soil Science, Vol. XV, No. 4, April, 1923. Available at https://edepot.wur.nl/200653 (accessed on 25/03/2021)

10. LVM dabas parka lepnums - dizas Tervetes priedes [The pride of LVM Nature Park - great Tervete pines]. 2020. https://doi.org/10.1097/00010694-192304000-00005 (in Latvian)

11. Matus F. J., Escudey M., Förster J. E., Gutiérrez M., Chang A. C. 2009. Is the Walkley-Black Method Suitable for Organic Carbon Determination in Chilean Volcanic Soils? Communications in Soil Science and Plant Analysis, Vol. 40, pp. $1862-1872$. https://doi.org/10.1080/00103620902896746

12. Namniece I. 2005. Priezu mezu augu sabiedribas dabas parka "Tervete" [Plant societies of pine forests in Tervete Nature Park], Diploma paper, Forest Faculty, Latvia University of Agriculture, Jelgava. (in Latvian)

13. Straupe I., Adamovics A. 2003. Zalaju floras daudzveidiba Tervetes dabas parka [Diversity of grassland flora in Tervete Nature Park]. Agronomijas Vestis, No. 5, pp. 165-171. (in Latvian)

14. Straupe I. 2009. Dabas parka „Tervete” dabas aizsardzibas plans [Nature protection plan for Tervete Nature Park]. Izstradatajs Latvijas Lauksaimniecibas universitates Meza fakultate. Available at https://www.daba.gov.lv/upload/File/DAPi_apstiprin/DP_ Tervete-09.pdf (accessed on 17/03/2019) (in Latvian)

15. Zviedris A., Matuzanis J. 1960. Latvijas PSR meza tipi [Forest types in Latvian SSR], Riga, Latvijas PSR Zinatnu Akademijas izdevnieciba (in Latvian). 